\title{
In vivo digestibility of different types of forages using sheep as a model of ruminants
}

Janina Stefanska, Marketta Rinne, Terttu Heikkilä and Seppo Ahvenjärvi

MTT Agrifood Research Finland, Animal Production Research, Jokioinen, Finland, e-mail

firstname.lastname@mtt.fi

\begin{abstract}
Digestibility of a forage is very important as it contributes to the energy and protein values and intake potential of the feed in ruminant production systems. The silages used in this digestibility trial present the range of variation encountered in practice of forages used within Finland: early cut grass (EG), late cut grass (LG), red clover (Trifolium pretense, RC) and whole-crop barley (Hordeum vulgare, WCB). Grass silages were a mixture of timothy (Phleum pretense) and meadow fescue (Festuca pratensis). EG, LG, RC and WCB were cut on 13 June (2006), 3 July (2006), 29 June (2006) and 2 August (2006), respectively. Grass and clover silages were wilted for 1 day and all silages were ensiled with AIV 2, and ensiled in round bales. Four rams (Dorset and Finnsheep $\times$ Texel crossbred) were used to estimate digestibility in a $4 \times 4$ Latin square experiment with four 3 -week experimental periods. The total digestibility was determined using total collection method by measuring daily forage intake and the amount of faeces excreted over the last 7 days of each period.

All silages were well preserved and had relatively high DM concentration, within $395-566 \mathrm{~g} / \mathrm{kg}$. The ash concentration in EG, LG, RC and WCB was 88, 70, 97 and $62 \mathrm{~g} / \mathrm{kg}$ DM. The respective CP concentrations were $180,113,163,71 \mathrm{~g} / \mathrm{kg}$ DM and NDF concentrations were 509, 623, 385and $548(\mathrm{~g} / \mathrm{kg}$ $\mathrm{DM})$.

The organic matter digestibility for EG, LG, RC and WCB was 0.751, 0.608, 0.645 and 0.618. There was a 20 day difference in the cutting dates of EG and LG resulting in 0.008 unit decrease in organic matter digestibility per day. Neutral detergent fibre digestibility was highest for early cut grass silage (0.74). and lowest for red clover (0.50) and whole-crop barley (0.51).

Forages vary greatly in their digestibility depending on species and maturity as shown by the results of the current study. The great variation emphasizes the importance of accurate routine digestibility analysis and need to analyze farm silages for ration formulation.
\end{abstract}

Key words: silage, grass, legume, red clover, whole-crop cereal, digestibility 


\section{Introduction}

Digestibility of forages is very important as it contributes to the energy and protein values (MTT 2006) and intake potential (Huhtanen et al. 2007) of the feed in ruminant production systems. For routine use, in vivo digestibility trials are too expensive, time-consuming and require a large quantity of the feed. Because of that, various in vitro methods for predicting digestibility of forages are used. In vitro methods do however not represent directly the digestibility obtained in vivo (Huhtanen et al. 2006). In vitro methods do not digest fibre as efficiently as rumen, and do not mimic many of the important digestive processes such as rates of particle breakdown and passage. Therefore the results obtained using in vitro methods should be verified by results obtained in vivo.

Sheep fed at maintenance level of feeding present a model of ruminant digestion commonly used as the basis of estimating digestibility in feed evaluation systems (eg. MTT 2006). They can be considered as the best estimate of the intrinsic digestibility value of a feed. The objective of this experiment was to determine the in vivo digestibility of four contrasting forages for subsequent use as a reference value for comparing the results with in vitro digestibility measurements (Stefanska et al. 2008) and measurements from lactating dairy cows (Ahvenjärvi et al., unpublished).

\section{Material and methods}

The silages used in this digestibility trial present the range of variation encountered in practice of forages used within Finland: early cut grass (EG), late cut grass (LG), red clover (Trifolium pretense, RC) and whole-crop barley (Hordeum vulgare, WCB). Grass silages were a mixture of timothy (Phleum pratense) and meadow fescue (Festuca pratensis). The EG, LG and WCB silages were prepared at MTT Jokioinen and RC silage at MTT Vihti. EG, LG, RC and WCB were cut on 13 June (2006), 3 July (2006), 29 June (2006) and 2 August (2006), respectively. Grass and clover silages were wilted for approximately $24 \mathrm{~h}$ and all silages were ensiled with a formic acid based additive (AIV 2, 76\% of formic acid and 5,5\% of ammoniumformate, Kemira GrowHow Ltd.) and ensiled in round bales.

Four rams (Dorset and Finnsheep $\times$ Texel crossbred) were used to estimate digestibility in a $4 \times 4$ Latin square experiment with 3 week experimental periods. The animals (mean live weight at the beginning of the experiment $46.7 \mathrm{~kg}$ ) were kept in metabolism cages and fed two equal meals per day.

During the first week, the sheep had ad libitum feeding, the second week was for acclimatization and third week for collection. During acclimatization and collection, dry matter (DM) intake was restricted to $41 \mathrm{~g} / \mathrm{kg}$ live weight ${ }^{0.75}$. The sheep received daily $30 \mathrm{~g}$ mineral mixture and $10 \mathrm{~g} \mathrm{NaCl}$ and water ad libitum. The total tract apparent digestibility was determined using total collection method by measuring daily forage intake and the amount of faeces excreted over the last 7 days of each period.

Representative samples of silages and faeces were taken each period for analyses and analyzed at the laboratory of MTT. Silage DM content was determined by oven drying at $105^{\circ} \mathrm{C}$ for $24 \mathrm{~h}$ and corrected for the loss of volatile substances (lactic acid, volatile fatty acids and ammonia) with equations given by Huida at al. (1986). Samples for analyses were dried at $60{ }^{\circ} \mathrm{C}$ for $48 \mathrm{~h}$ and milled through $1 \mathrm{~mm}$ screen. The silage and faecal samples were analysed for ash at $600{ }^{\circ} \mathrm{C}$ for $2 \mathrm{~h}$ and for crude protein (CP) using the Dumas method (Leco EP 428 nitrogen analyser). The silages were analysed for VFA using a method described by Huhtanen et al. (1998) and ammonia N using a method described by McCullough (1967). Lactic acid was analysed according to Haacker et al. (1983). Ethanol was measured with an enzymatic kit (Cat No. 981680, KONE Instruments Corporation, Espoo; Finland) using the selective clinical chemistry analyser Pro 981489 according to application instructions given by KONE. Water soluble carbohydrates (WSC) were analyzed according to Somogyi (1945).

Neutral detergent fibre (NDF) was analysed according Van Soest et al. (1991) in the presence of sodium sulphite but without $\alpha$ - amylase treatment except for WCB and presented as ash free. Acid detergent fibre (ADF) and lignin were analysed using a method described by Robertson and van Soest (1981). Indigestible NDF (iNDF) concentration was estimated using an in situ method. The samples were incubated in polyester bags (pore size $17 \mu \mathrm{m}$ ) for 12 days in the rumen of 2 dairy cows consuming a foragebased ration. After the incubation, the bags were boiled for $1 \mathrm{~h}$ in neutral detergent solution and ashed to 
present the results ash free. Organic matter cellulase solubility was analysed using a method described by Nousiainen et al. (2003). The iNDF and pepsin-cellulase solubility were converted to OMD using the forage type specific regression equations presented by Huhtanen et al. (2006, 2008). OMD was also estimated using in vitro gas production technique as described by Rinne et al. (2006).

Potentially digestible NDF (pdNDF) was calculated as NDF concentration - iNDF concentration. Cellulose was calculated as ADF - lignin and hemicellulose was calculated as NDF - ADF. Silage DM intake (SDMI) index was calculated according to Huhtanen et al. (2007) and Rinne et al. (2008). Digestibility was calculated as: (amount consumed - amount excreted in faeces) / amount consumed.

The results were analysed statistically using the GLM procedure of SAS using a model $\mathrm{y}_{\mathrm{ijk}}=\mu+$ $A_{i}+P_{j}+F_{j}+e_{i j k}$, where $\mu$ is the overall mean, $A, P$ and $F$ the effects of sheep, period and forage and e the unexplained variation. The treatment mean values were compared using the Duncan's multiple range test.

\section{Results and discussion}

The raw material for silages is characterized in Table 1 and the final silages in Table 2. The silages were rather typical for the type of forages they represented (see e.g. Huhtanen et al. 2006). The early and late cut silages had a 20-day difference in harvest time, which resulted in marked increases in NDF and iNDF concentrations while ash and $\mathrm{CP}$ concentration and digestibility decreased clearly. The RC silage had a relatively low NDF concentration and digestibility but high iNDF concentration. The high ash and CP concentrations are also typical for red clover silages. The WCB silage had low ash and CP concentrations but high iNDF concentration.

The changes in the plant material during ensiling were mainly typical (see eg. Huhtanen et al. 2005). There were very little differences in the ash and CP concentration between the raw materials and the silages in all forage types. There seemed to be more hydrolysis of NDF and even iNDF in red clover compared to the grasses. There was clearly higher NDF and iNDF concentration in the WCB silage, but lower DM concentration compared to the raw material. These changes are difficult to explain, and may be an artefact created by difficulties in representative sampling of whole crop cereals. Whole crop silages are also difficult to analyse for NDF, because they contain considerable amounts of starch in the grains. It is necessary to use heat-stable $\alpha$-amylase in the analysis to degrade the starch, which will otherwise erroneously be included in the NDF fraction (Mertens, 2002).

All silages were well preserved and had a relatively high DM concentration ranging from 402 to $566 \mathrm{~g} / \mathrm{kg}$. Consequently, $\mathrm{pH}$ values were relatively high and concentrations of fermentation end products low.

Table 1. Description of the early cut grass (EG), late cut grass (LG), red clover (RC) and whole crop barley (WCB) used as the raw material for silages.

\begin{tabular}{lcccc}
\hline & EG & LG & RC & WCB \\
\hline Date of cut in 2006 & 13 June & 3 July & 29 June & 2 August \\
Dry matter (DM) at baling (g/kg) & 394 & 537 & 357 & 465 \\
In DM (g/kg DM) & & & & \\
Ash & 85 & 70 & 95 & 56 \\
Crude protein & 173 & 110 & 166 & 81 \\
Neutral detergent fibre (NDF) & 519 & 630 & 403 & 404 \\
Indigestible NDF & 45 & 153 & 168 & 94 \\
& & & & \\
D-value (g/kg DM) based on: & 716 & 586 & 578 & 684 \\
iNDF & 734 & 640 & 639 & 707 \\
Pepsin-cellulase solubility & & & & \\
\hline
\end{tabular}


Table 2. Chemical composition and fermentation quality of early cut grass (EG), late cut grass (LG), red clover (RC) and whole crop barley (WCB) silages.

\begin{tabular}{lcccc}
\hline & EG & LG & RC & WCB \\
\hline Dry matter (DM, g/kg) & 395 & 566 & 386 & 402 \\
pH & 4.94 & 4.99 & 4.48 & 4.36 \\
Silage DM intake index & 115 & 89 & 115 & 97 \\
OM cellulase solubility (g/kg OM) & 791 & 690 & 732 & 737 \\
D-value (g/kg DM) based on: & & & & \\
iNDF & 714 & 575 & 618 & 601 \\
Pepsin-cellulase solubility & 691 & 575 & 617 & 632 \\
In vitro gas production & 707 & 573 & 623 & 611 \\
In DM (g/kg DM) & & & & \\
Ash & & & & \\
Crude protein & 87.6 & 70.3 & 97.2 & 61.9 \\
Neutral detergent fibre (NDF) & 180 & 113 & 163 & 72 \\
Acid detergent fibre (ADF) & 509 & 623 & 385 & 517 \\
Lignin & 274 & 333 & 247 & 265 \\
Hemicellulose (NDF - ADF) & 25.5 & 40.9 & 48.7 & 31.8 \\
Cellulose (ADF - lignin) & 234 & 289 & 137 & 282 \\
Indigestible NDF & 248 & 292 & 199 & 233 \\
& 45 & 162 & 128 & 149 \\
Fermentation quality (g/kg DM) & & & & \\
Water soluble carbohydrates & & & & \\
Lactic acid & 116 & 107 & 82 & 101 \\
Acetic acid & 3.8 & 1.0 & 24 & 18 \\
Propionic acid & 6.1 & 4.7 & 8.4 & 7.2 \\
Isobutyric acid & 0.13 & 0.09 & 0.15 & 0.13 \\
Butyric acid & 0 & 0.005 & 0.005 & 0.005 \\
Isovaleric acid & 0.112 & 0.072 & 0.075 & 0.405 \\
Valeric acid & 0.075 & 0.095 & 0.102 & 0.122 \\
Ethanol & 0 & 0 & 0.002 & 0.067 \\
In total N (g/kg N) & 7.3 & 4.7 & 2.1 & 8.4 \\
Ammonium N & 36 & 29 & 41 & 47 \\
Soluble N & 673 & 507 & 327 & 623 \\
\hline
\end{tabular}

The feed intakes and digestibility results are presented in Table 3. The ad libitum DM intake of EG and $\mathrm{RC}$ was significantly higher than that of LG and WCB. However, there were no significant differences between the DM and OM intake of the silages during the collection period, when restricted feeding was used. There were significant differences in $\mathrm{CP}$ and NDF intakes reflecting the differences in the composition of the forages.

The silages differed clearly in digestibility. EG was superior compared to all other silages in OM and NDF digestibility. There was a 20 day difference in the cutting dates of EG and LG resulting in 0.008 unit decrease in OMD per day. The CP digestibility of WCB was very poor, but because this is the apparent digestibility, the very low $\mathrm{CP}$ concentration contributes to the low digestibility coefficient. The NDF and pdNDF digestibilities were higher in grasses than in RC and WCB, while for neutral detergent solubles digestibility, LG was inferior compared to the other silages. 
The relationships between OMD based on the iNDF, OMS and gas production (Rinne et al. 2006) methods and values determined in vivo are presented in Figure1. The relationships were good in accordance with Huhtanen et al. (2006) and Stefanska et al. (2008).

Figure 2 demonstrates the relationship between SDMI index and ad libitum silage DM intake of sheep. The relationship was very good although the SDMI index is derived using data from lactating dairy cows. In calculation of SDMI index for RC and WCB, proportions of 1 were used in the equation instead of the recommended maximum of 0.5. Of the current forages, EG had the highest and LG the lowest SDMI. The main reason for a low SDMI for LG was its low D-value ( $570 \mathrm{~g} / \mathrm{kg} \mathrm{DM})$.

\section{Conclusions}

Forages vary greatly in their digestibility depending on species and maturity as shown by the results of the current study. The great variation emphasizes the importance of accurate routine digestibility analysis and need to analyze farm silages for ration formulation.

Table 3. Feed intake and digestibility of early cut grass (EG), late cut grass (LG), red clover (RC) and whole crop barley (WCB) silages in sheep.

\begin{tabular}{lccccc}
\hline & EG & LG & RC & WCB & SEM $^{1)}$ \\
\hline Live weight (LW, kg) & 46.6 & 46.7 & 46.1 & 47.1 & 0.29 \\
& & & & & \\
Feed intake (g/d) & & & & & \\
Dry matter (DM) & 751 & 768 & 763 & 730 & 20.1 \\
Silage DM & 727 & 745 & 741 & 708 & 20.8 \\
Organic matter & 663 & 692 & 669 & 664 & 18.9 \\
Crude protein & $131^{\mathrm{a}}$ & $84^{\mathrm{b}}$ & $121^{\mathrm{a}}$ & $51^{\mathrm{c}}$ & 3.08 \\
$\quad$ Neutral detergent fibre & $370^{\mathrm{b}}$ & $464^{\mathrm{a}}$ & $285^{\mathrm{c}}$ & $366^{\mathrm{b}}$ & 12.3 \\
Feed intake (g per kg LW ${ }^{0.75}$ ) & & & & & \\
Collection period & 40.8 & 41.7 & 41.7 & 39.3 & 1.10 \\
Ad libitum period & $81.5^{\mathrm{a}}$ & $64.2^{\mathrm{b}}$ & $80.9^{\mathrm{a}}$ & $63.7^{\mathrm{b}}$ & 3.60 \\
& & & & & \\
Digestibility (g/g) & & & & & \\
Dry matter & $0.751^{\mathrm{a}}$ & $0.608^{\mathrm{c}}$ & $0.645^{\mathrm{b}}$ & $0.618^{\mathrm{bc}}$ & 0.0089 \\
Organic matter & $0.769^{\mathrm{a}}$ & $0.613^{\mathrm{c}}$ & $0.648^{\mathrm{b}}$ & $0.631^{\mathrm{bc}}$ & 0.0074 \\
D-value (g/kg DM) & $702^{\mathrm{a}}$ & $570^{\mathrm{b}}$ & $585^{\mathrm{b}}$ & $592^{\mathrm{b}}$ & 6.5 \\
Crude protein & $0.756^{\mathrm{a}}$ & $0.625^{\mathrm{b}}$ & $0.617^{\mathrm{ab}}$ & $0.451^{\mathrm{c}}$ & 0.0162 \\
Neutral detergent fibre & $0.786^{\mathrm{a}}$ & $0.597^{\mathrm{b}}$ & $0.500^{\mathrm{c}}$ & $0.513^{\mathrm{c}}$ & 0.0154 \\
Neutral detergent solubles ${ }^{2)}$ & $0.747^{\mathrm{a}}$ & $0.647^{\mathrm{b}}$ & $0.758^{\mathrm{a}}$ & $0.775^{\mathrm{a}}$ & 0.0073 \\
pdNDF & $0.863^{\mathrm{a}}$ & $0.808^{\mathrm{ab}}$ & $0.749^{\mathrm{b}}$ & $0.722^{\mathrm{c}}$ & 0.0230 \\
\hline
\end{tabular}

${ }^{1)}$ Standard error of the mean

${ }^{2)}$ Organic matter - neutral detergent fibre (NDF)

${ }^{3)}$ Potentially digestible NDF $=$ NDF - indigestible NDF

Means with different superscripts differ statistically significantly $(\mathrm{P}<0.05)$ based on Duncan's multiple range test. 


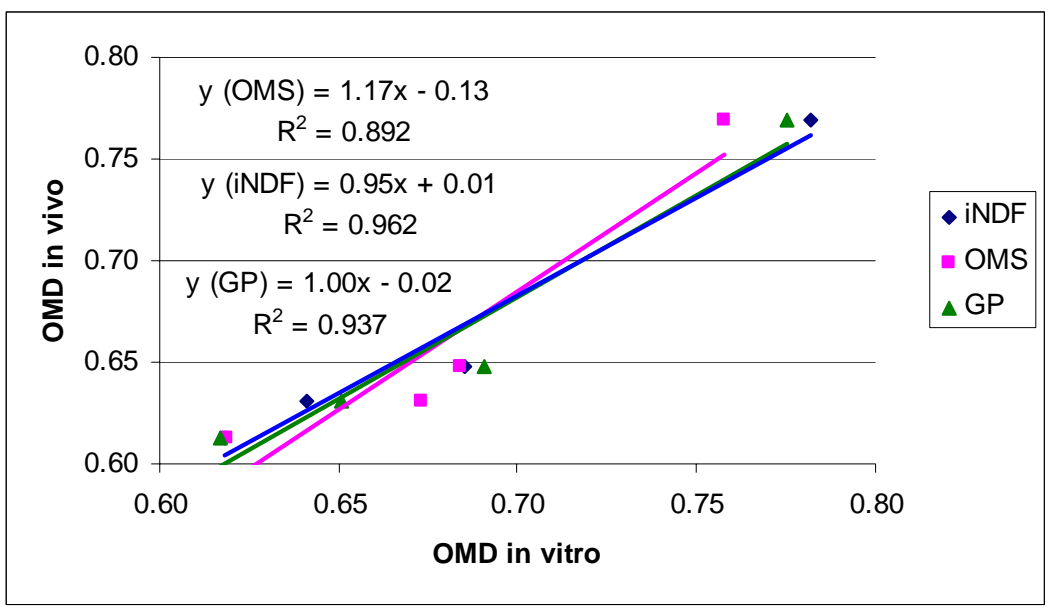

Figure 1. Relationships between different methods (iNDF $=$ indigestible neutral detergent fibre concentration, OMS = organic matter pepsin cellulase solubility, GP = in vitro gas production) and in vivo organic matter digestibility (OMD).
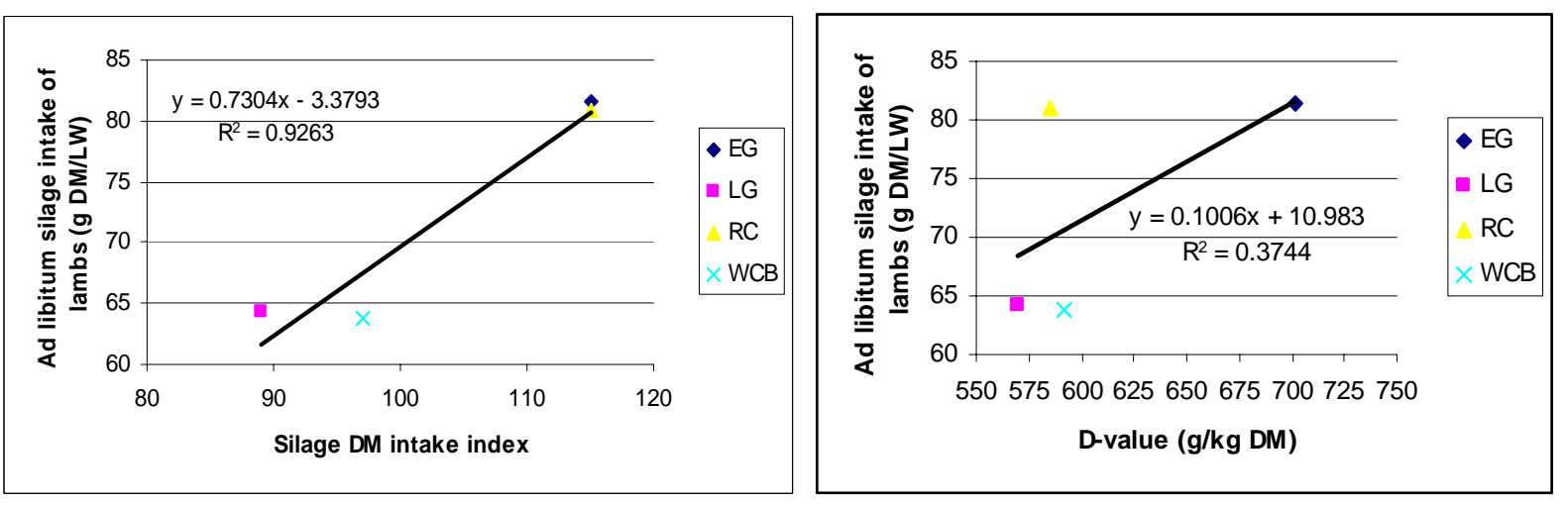

Figure 2. Silage dry matter (DM) intake index was more closely related to the ad libitum silage intake in sheep than D-value. In calculation of SDMI index for red clover and whole-crop barley, proportions of 1 were used in the equation instead of the recommended maximum of 0.5 .

\section{References}

Haacker, K., Block, H.J. \& Weissbach, F. 1983. Zur kolorimetrischen Milchsäurebestimmung in Silagen mit pHydroxydiphenyl. (On the colorimetric determination of lactic acid in silages with p-hydroxydiphenyl). Archive fur Tierenährung 33: 505-512.

Huhtanen, P.J., Blauwiekel, R. \& Saastamoinen, I. 1998.Effects of intraruminal infusions of propionate and butyrate with two different protein supplements on milk production and blood metabolites in dairy cows receiving grass silage based diet. Journal of the Science of Food and Agriculture 77: 213-222.

Huhtanen, P., Nousiainen, J. \& Rinne, M. 2005. Prediction of silage composition and organic matter digestibility from herbage composition and pepsin-cellulase solubility. Agricultural and Food Science 14: 154-165.

Huhtanen, P., Nousiainen, J. \& Rinne, M. 2006. Recent developments in forage evaluation with special reference to practical applications. Agricultural and Food Science 15: 293-323. 
Huhtanen, P., Rinne, M. \& Nousiainen, J. 2007. Evaluation of the factors affecting silage intake of dairy cows: a revision of the relative silage dry-matter intake index. Animal 1: 758-770.

Huhtanen, P., Nousiainen, J.,\& Rinne, M. 2008. Karkearehujen sulavuuden määritys tarkentunut. Maataloustieteen Päivät 2008.

Huida, L., Väätäinen, H. \& Lampila, M. 1986. Comparison of dry matter contents in grass silages as determined by oven drying and gas chromatographic water analysis. Annales Agriculturae Fenniae 25: 215 -230.

McCullough, H. 1967. The determination of ammonia in whole blood by direct colorimetric method. Clinica Chimica Acta 17: 297-304.

Mertens, D.R. 2002. Gravimetric determination of amylase-treated neutral detergent fiber in feeds with refluxing in beakers or crucibles: collaborative study. J.A.O.A.C. Inter. 85:1217-1240.

Nousiainen, J., Rinne, M., Hellämäki, M. \& Huhtanen, P. 2003. Prediction of the digestibility of the primary growth of grass silages harvested at different stages of maturity from chemical composition and pepsin-cellulose solubility. Animal Feed Science and Technology, 103: 97-111.

Robertson, J.B. \& Van Soest, P. J. 1981. The detergent system of analysis and its application to human foods. In: James, W.D.T. \& Theander, O. (eds.). The Analyses of dietary Fibre in Foods. New York, NY, Marcell Dekker. P. 123-158.

Rinne, M., Olt, A., Nousiainen, J., Seppälä, A., Tuori, M., Paul, C. Fraser, M. D. \& Huhtanen, P. 2006.

Prediction of legume silage digestibility from various laboratory methods. Grass and Forage Science 61. 354 - 362.

Rinne, M., Huhtanen P. \& Nousiainen, J. 2008. Säilörehun ja koko rehuannoksen syönti-indeksit auttavat lypsylehmien ruokinnan suunnittelussa. Maataloustieteen Päivät 2008.

Somogyi, M. 1945. A new reagent for the determination of sugars. Journal of Biolgical Chemistry 160: 61-68.

Stefanska, J., Rinne, M., Seppälä, A.,Vanhatalo, A., Nousiainen, J. \& Huhtanen, P. 2008. Estimation of pdNDF digestion rate and $\mathrm{OM}$ digestibility of forages using in vitro gas production technique.Biodiversity and animal feed futre challenges for grassland production. Submitted to: $22^{\text {nd }}$ General Meeting of the European Federation, Uppsala, Sweden. June 9-12, 2008-

Van Soest, P.J., Robertson, J. B., \& Levis, B.A. 1991. Methods for dietary fibre neutral detergent fibre and nonstarch polysaccharides in relation to animal nutrition. Journal of Dairy Science 74: 3583-3597. 